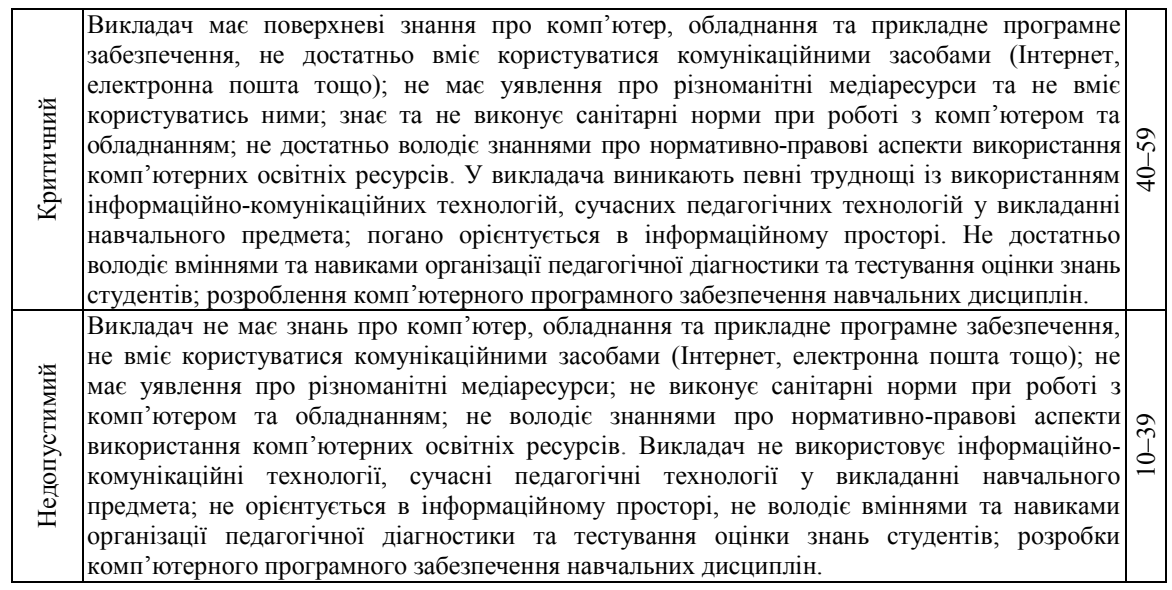

Беззаперечною метою впровадження інформаційно-комунікаційних технологій $\epsilon$ формування в особистості сучасної інформаційної культури, тобто володіння навичками роботи 3 електронними, цифровими засобами. Така людина $\epsilon$ підготовленою до життя в інформаційному суспільстві. Ми наголошуємо на тому, що науково-педагогічним працівникам взагалі, а викладачам іноземних мов ВНЗ зокрема, необхідно звертати постійну увагу на нові технології роботи з інформацією та розвиток комп'ютерної техніки, щоб бути обізнаним, компетентним у зазначеній сфері. Перспективу подальшого дослідження ми вбачаємо в розробленні тренінгів для розвитку зазначеної нами ключової компетентності.

\title{
Література
}

1. Про затвердження норм часу для планування і обліку навчальної роботи та переліків основних видів методичної, наукової й організаційної роботи педагогічних і науково-педагогічних працівників вищих навчальних закладів : наказ М-ва освіти і науки України № 450 від 07.08.02 p. // Інформ. зб. М-ва освіти і науки України. - 2002. - № 22. - С. 3-11. 2. Кваліфікаційні вимоги до професійної діяльності педагогічних працівників // Збірник матеріалів за результатами дослідження / за заг. ред. Г. В. Сльникової. Київ-Черкаси, 2010. - 144 с. 3. Сгорова В. В. Розвиток ключових компетентностей науковопедагогічних працівників у системі методичної роботи вищого навчального закладу: дис. ... канд. пед. наук: 13.00 .04 / Єгорова Вероніка В'ячеславівна. - К., 2011. - 288 с. 4. Падалка О. С. Інтенсивні технології навчання / Падалка Олег Семенович // Вища освіта України. - 2002. - № 2. - С. 91-95. 5. Цідило І. М. Вплив ІКТ-компетентності педагога на використання інноваційних технологій у навчальному процесі / Цідило Іван Миколайович // Професійні компетенції та компетентності вчителя: матеріали регіон. наук.-практ. семінару. - Тернопіль : Вид-во ТНПУ ім. В. Гнатюка, 2006. - С. 44-46.

Валентин Златніков

\section{ЕТАПИ НАВЧАННЯ ПРОФЕСІЙНО-ОРІЕНТОВАНОГО АУДІЮВАННЯ АНГЛІЙСЬКОЮ МОВОЮ КУРСАНТІВ ВИЩИХ ВІЙСЬКОВИХ НАВЧАЛЬНИХ ЗАКЛАДІВ}

Златніков В. Г. Етапи навчання професійно-орієнтованого аудіювання англійською мовою курсантів вищих військових навчальних закладів.

Стаття присвячена проблемі навчання курсантів вищих військових навчальних закладів професійно-орієнтованого аудіювання англійською мовою. У статті схарактеризовано основні етапи роботи з аудіотекстами, виокремлено педагогічні умови, які впливають на ефективність навчання аудіювання на кожному із визначених етапів.

Ключові слова: професійно-орієнтоване аудіювання, віськово-спеціальна мовна підготовка, педагогічні умови, уміння професійно-орієнтованого аудіювання, комплекс вправ. 
Златников В. Г. Этапы обучения профессионально-ориентированному аудированию на английском языке курсантов высших военных учебных заведений.

В статье исследуется проблема обучения профессионально-ориентированному аудированию на английском языке курсантов высших военных учебных заведений. В статье охарактеризованы основные этапы работы с аудиотекстами, выделены педагогические условия, которые влияют на эффективность обучения аудированию на каждом из определенных этапов.

Ключевые слова: профессионально-ориентированное аудирование, военно-специальная языковая подготовка, педагогические условия, умения профессионально-ориентированного аудирования, комплекс упражнений.

Zlatnikov V. G. Stages of teaching professionally-orientated listening comprehension in English of cadets of higher military educational establishments.

This article is devoted to the problem of training of professionally-orientated listening comprehension in English of cadets of higher military educational establishments. The paper describes the main stages of work with audiotexts. Pedagogical conditions that influence the effectiveness of teaching listening comprehension are defined.

Key words: professionally-orientated listening comprehension, military special language training, pedagogical conditions, skills in professionally-orientated listening comprehension, complex of exercises.

Сучасний етап розвитку України позначився значним розширенням міжнародних контактів країни майже в усіх суспільних сферах. У зв'язку з європейськими та євроатлантичними прагненнями, тенденціями до інтеграції європейських країн все більшої актуальності набуває проблема володіння громадянами України іноземною мовою.

Співробітництво України 3 військовими відомствами зарубіжних країн $є$ важливим складником міжнародного співробітництва держави і має особливе значення для зміцнення національної безпеки і оборони України. Формування іншомовної мовленнєвої компетентності в майбутніх офіцерів $є$ одним з важливих завдань мовної підготовки курсантів у ВВНЗ.

Навчання майбутніх офіцерів іноземної мови передбачає розвиток навичок та вмінь аудіювання, говоріння (монологічна та діалогічна мова), читання, письма. Аудіювання складає основу всього процесу оволодіння іноземною мовою і $є$ обов'язковим складником формування в курсантів ВВНЗ іншомовної комунікативної компетенції.

Аналіз наукової літератури показує, що значну увагу проблемі навчання аудіювання приділяють у своїх дослідженнях О. Бігич, М. Жинкін, М. Ляховицький, О. Тарнапольський та інші.

Мета статті полягає у визначенні етапів навчання професійно-орієнтованого аудіювання англійською мовою курсантів вищих військових навчальних закладів (ВВНЗ).

Етапний характер навчання аудіювання англомовної професійно спрямованої інформації підкреслює у дослідженнях Н. Новоградська-Морська, пропонує виокремлювати попередній, підготовчо-розвивальний та виконавчий етапи навчання аудіювання професійно спрямованих відеофономатеріалів [5, с. 39].

Ми поділяємо позицію В. Буряка [2], який, вивчаючи особливості формування розумової культури студентів, визначає такі основні етапи технології навчання, як: підготовчоорганізаційний, змістово-процесуальний та контрольно-корекційний, що розкривають сутність дидактичної структури процесу навчання.

Виходячи 3 положення про етапний характер реалізації методики навчання курсантів професійно-орієнтованого аудіювання англійською мовою та врахування його особливостей, було розроблено методику навчання професійно-орієнтованого аудіювання англійською мовою курсантів вищих військових навчальних закладів.

Функціональна структура організації роботи з матеріалом для аудіювання передбачає три етапи: підготовчо-організаційний (або дотекстовий), змістовий (або текстовий) та творчий (або післятекстовий). Зазначені компоненти функціональної структури методики навчання професійно-орієнтованого аудіювання виокремлено відповідно до логіки роботи 3 аудіоматеріалом. Кожний із зазначених етапів зорієнтований на досягнення конкретних дидактичних цілей. Це зумовлює необхідність добору відповідних вправ, виконання яких на 
заняттях 3 військово-спеціальної мовної підготовки сприяє досягненню поставленої дидактичної мети на кожному з етапів роботи над аудіоматеріалом.

Підготовчо-організаційний (дотекстовий) етап спрямований на виконання тренувальних вправ, які забезпечують перцептивно-сенсорну основу аудіювання, знімають труднощі лінгвістичного і психологічного характеру. Змістовий (текстовий) етап роботи з аудіоматеріалом зорієнтований на удосконалення навичок перцептивного оброблення інформації, розвиток аудіювання як виду мовленнєвої діяльності, вдосконалення в курсантів умінь професійноорієнтованого аудіювання, розвиток стратегій сприйняття аудитивного тексту. Творчий (або післятекстовий) етап спрямований на формування в курсантів умінь використовувати інформацію, яку містять аудіоповідомлення, в умовах реального іншомовного спілкування.

Підготовчо-організаційний (дотекстовий) етап готує курсантів до усвідомленого прослуховування на наступному етапі. Він складається з фази набуття мовних знань, фази формування мовленнєвих умінь, фази використання знань і умінь. Мета цього етапу роботи 3 текстом полягає в забезпеченні готовності курсантів до сприйняття мовних засобів у процесі спілкування. Дотекстовий етап представлений підготовчими (тренувальними) вправами: 1) вправи для подолання мовних труднощів; 2) вправи для подолання психологічних труднощів.

Із досліджень вітчизняних і зарубіжних методистів і психолінгвістів відомо, що вміння смислового оброблення інформації грунтуються на вміннях іiі перцептивного оброблення. Однак найважливіша роль на цьому етапі належить формуванню основних умінь оперування мовним матеріалом, необхідним для аудіювання, а також актуалізації накопиченого мовного i мовленнєвого матеріалу під час репродукції.

На першому етапі роботи з текстом студенти оволодівають загальним ядром системи мови, що визначається межами майбутнього аудіотексту. Певний мінімум лексики і граматики, яким опановують студенти на дотекстовому етапі, складає базовий матеріал тексту.

Наведемо приклади вправ, що використовуються на дотекстовому етапі роботи 3 аудіотекстом: прослухайте словосполучення і повторіть за диктором, дотримуючись ритму та інтонації; прослухайте речення, визначте його комунікативний тип, повторіть це речення за диктором; прослухайте речення, повторіть словосполучення, що містять абревіатури.

Важливою умовою досягнення позитивного результату на дотекстовому етапі роботи 3 аудіоматеріалом $є$ створення сприятливого психологічного клімату на занятті. Реалізація зазначеної особливості навчання сприяє не лише ефективному подоланню в курсантів фонетичних, граматичних та лексичних труднощів, але й налаштовує слухачів на подальшу продуктивну співпрацю.

Змістовий (текстовий) етап роботи з аудіоматеріалом спрямований на розвиток аудіювання як виду мовленнєвої діяльності, вдосконалення в курсантів умінь професійно-орієнтованого аудіювання. Презентація аудіотексту викладачем передбачає фазу набуття навичок сприймання і розуміння безперервного монологічного висловлювання, фазу набуття навички конспектування ключових слів і основних думок, фазу використання отриманих знань і розуміння змісту почутого. Метою цього етапу також $є$ розвиток стратегій сприйняття аудіотексту.

Текстовий етап $є$ основою розвитку власне мовленнєвого вміння в аудіюванні, необхідного студентам для спілкування, оскільки $є$ одним 3 комунікативних умінь. На цьому етапі відбувається удосконалення навичок перцептивного оброблення інформації і розвиток аудіювання як виду мовленнєвої діяльності. Задля цього забезпечується активна, цілеспрямована рецептивна діяльність студентів, у процесі якої розвиваються вміння аудіювання, спрямовані на розуміння повідомлення.

Текстовий етап охоплює дві групи вправ: 1) мовленнєві вправи в аудіюванні; 2) мовленнєві вправи для навчання підготовленого монологічного та діалогічного мовлення.

Наведемо приклади вправ, що використовуються на текстовому етапі: прослухайте репліки диктора та дайте відповідь на них власними репліками, адекватними за змістом; прослухайте мікродіалог (мікромонолог). Після прослуховування відтворіть його кілька разів, змінюючи фразовий наголос у кожній фразі; прослухайте аудіофрагмент та заповніть пропущені місця в надрукованому варіанті.

Під час організації роботи з аудіоматеріалом на текстовому етапі доцільно звертати увагу на реалізацію педагогічної умови активізації діяльності курсантів на основі особистіснодіяльнісного та комунікативного підходів. Урахування індивідуальних особливостей курсантів 
сприяє розвитку інтересу та забезпечує позитивну мотивацію вивчення англійської мови за професійним спрямуванням. Підбір аудіотекстів та вправ до них з урахуванням інтересів та рівня підготовленості курсантів до аудіювання формує активність, самостійність та переживання почуття особистої значущості виконаної роботи. Використання комунікативних ситуацій моделює реальні умови іншомовного спілкування, сприяє зануренню курсантів у середовище професійно-орієнтованого спілкування англійською мовою, формує розуміння та бажання вдосконалювати власний рівень військово-спеціальної мовної підготовки.

Творчий (або післятекстовий) етап спрямований на формування в курсантів готовності до природного спілкування, що передбачає вільне вираження своїх думок і намірів. Він спрямований на використання вмінь і отриманої інформації для висловлення своєї думки за темою аудіотексту, розвиток умінь колективної творчої роботи в мікрогрупах по 3-5 осіб, парної роботи. Отже, аудіотекст стає стимулом до обговорення отриманої інформації. Студенти обговорюють в парах і малих групах, що вони знають з теми.

Післятекстовий етап включає групу вправ, спрямованих на використання інформації, отриманої під час аудіювання текстів професійного спрямування для навчання непідготовленого монологічного та діалогічного мовлення.

Під непідготовленим мовленням розуміємо природну мовленнєву діяльність, що передбачає такий рівень розвитку навичок і вмінь, за якого студент здатний практично безпомилково і в природному, не уповільненому для цієї мови темпі мобілізувати вивчений мовний матеріал задля здійснення реальної комунікації [6, с. 54]. Непідготовлене мовлення характеризується як такий рівень володіння іноземною мовою, за якого мовець може без підготовки і без прямих спонукань співрозмовника до говоріння використовувати засвоєний матеріал у ситуаціях, що раніше не зустрічалися [3, с. 76]. П. Гурвіч визначає непідготовлене мовлення як «уміння вирішувати нові розумові завдання без підготовки в часі і без прямих спонукань до говоріння, оперуючи засвоєним мовним матеріалом як у нових комбінаціях, так і в тих, що зустрічалися раніше»[3, с. 75$]$.

Наведемо приклади завдань, що використовуються на післятекстовому етапі: прослухайте аудіотекст, складіть план, відтворіть зміст за планом; прослухайте аудіотекст, запропонуйте назву до нього; прослухайте текст (теле-/радіопередачу, пісню, вірш, розповідь тощо) і висловіть свою позицію щодо запропонованої тематики; прослухайте аудіофрагмент, дайте відповідь на запитання: «Наскільки повно відображена в тексті порушена проблема?»; прослухайте фрагмент аудіотексту, спрогнозуйте його закінчення.

Відповідно до основної мети післятекстової роботи 3 аудіоматеріалом - формування в курсантів умінь використовувати інформацію, яку містять аудіоповідомлення, в умовах реального іншомовного спілкування - важливим аспектом організації навчальної роботи на цьому етапі $є$ реалізація на заняттях з військово-спеціальної мовної підготовки імітаційно-ігрового підходу.

Отже, у навчанні майбутніх офіцерів професійно-орієнтованого аудіювання англійською мовою доцільно виокремлювати три етапи роботи з аудіотекстом (підготовчо-організаційний (дотекстовий), змістовий (текстовий) і творчий (післятекстовий)). Етапний характер реалізації методики навчання аудіювання англійською мовою сприяє ефективній організації навчальної діяльності курсантів на заняттях з військово-спеціальної мовної підготовки.

\section{Література}

1. Бігич О. Б. Методика формування іншомовної компетенції в аудіюванні у студентів мовних спеціальностей / О. Б. Бігич // Методика формування міжкультурної іншомовної комунікативної компетенції: [курс лекцій]. - К. : Ленвіт, 2011. - С. 175-188. 2. Буряк В. К. Умови та засоби самоосвіти студентів у вищій школі / В. К. Буряк // Рідна школа. - 2002.- № 6. - С. 18-29. 3. Гурвич П. Б. Обучение устной экспрессивной речи на факультетах иностранных языков: дисс. ... докт. пед. наук: 13.00 .02 / Петр Борисович Гурвич. - Владимир, 1971. - 536 с. 4. Ляховицкий М. В. Методика преподавания иностранных языков / М. В. Ляховицкий. - М. : Высшая школа, 1981. 159 с. 5. Новоградська-Морська Н. А. Навчання майбутніх економістів аудіюванню англомовної професійно спрямованої телевізійної інформації / Н. А. Новоградська-Морська // Іноземні мови. 2005. - № 2. - С. 38-42. 6. Обносов Н. С. К вопросу о содержании понятия неподготовленной речи и классификации упражнений, направленных на ее развитие / Н. С. Обносов // Иностранные языки в школе. - 1968. - № 3. - С. 51-57. 